years in a young man's life that he will look back on them with pride and affection in the same sort of way that many men do to their undergraduate days.

Much is already being done in private industry, but Sir Harold thinks that the biggest problems facing the nationalized industries in Britain are those of human relations, and to these the continuous process of further education at all levels is the answer. The main objective of such education must be the improvement of human relations, the establishment of mutual confidence and community of interest and a realization of the difficulties which Britain has to face and their inevitable and apparently frustrating consequences. In no other way is it possible to hope to escape from the misunderstandings and mistakes which ultimately affect everyone adversely.

Some day it must be realized that the inescapable effect of industrial disputes and restrictive practices is to lower the standard of living. Sir Harold reviewed briefly what is already being done in Great Britain to meet this need in the nationalized industries and the Civil Service, and he quoted with approval Sir Fred Clarke's view that the essence of adult education lies in its appeal to the adult student as a commitment to action. Such a student wants to know what he is to do, both as a person and as a citizen, and the objective should therefore be, not so much formulated knowledge, but rather a rational interpretation of experience.

In bringing the Lecture to a conclusion, Sir Harold insisted that the two problems are interdependent, one of increased productivity and thus retaining for Great Britain its place in the world to-day and its standards of living and way of life, and the other of curing the maladjustments and lack of mutual confidence in a rapidly changing society. The best hope of securing real community of interest and giving individual satisfaction lies in joint consultation and recognition of the contribution that each individual can. make and his responsibility to do so. The new range of responsibilities that joint consultation implies can only be met by opening a new chapter in education in Great Britain, both for management and for the trade unions. This is the most urgent task for further education and its immediate opportunity.

\section{TRAINING OF SUPERVISORS AND OF ORERATIVES IN INDUSTRY}

TAKEN together, the two Productivity Team 1 reports*, on the training of supervisors and of operatives respectively, form a counterpart to the report on trade schools of the Continent issued as a result of a visit twenty years ago by two Board of Education inspectors, A. Abbott and J. E. Dalton. Indeed, one of their most interesting features is the extent to which the recommendations of the Productivity Teams reiterate what was urged by Mr. Abbott in his subsequent book "Education for Industry and Commerce in England". There we find the same stress laid on the bearing of technical education on industrial efficiency, economic recovery * Productivity Reports. Training of Operatives. Report of one of
four Specialist Teams which visited the United States of America in 1951 to study Problems of Training for Industry. Pp. xii +52.38 . Training of Supervisors. Report of a visit to the U.S.A. in 1951 of a Specialist Team to study Supervisor Training and Selection. Pp.
viil +56. 2s. $6 d$. (London and New York: Anglo-A merican Council on Productivity, 1951.) and the maintenance of standards of living; thus early was the inefficiency of some industries attributed to their failure to utilize the scientific knowledge available to them. That failure was, it is true, in Mr. Abbott's view, due to those industries not employing enough men with the necessary wide and thorough scientific training, but by and large there is a disturbing similarity between the reflexions provoked twenty years ago by an examination of technical education on the Continent in comparison with that in Great Britain and the impressions derived by the Productivity Teams in their examination of the American scene last year.

There are differences and changes, especially in detail, but the generalization is broadly true, and it does not augur well for the industrial and economic future of Britain that so little advance should be recorded in two decades. When all allowance is made for the differences in background, and between the American and the British way of life, both these reports leave the impression that the main difference between the American scene and the British scene is psychological. In all types of training, the eagerness of the individual to be trained is a basic assumption in the United States: the individual readily accepts a way of life in which his frosperity is directly proportional to his own efforts and ability, and there is a stimulating atmosphere of vitality which allows no practices to be unalterably established. New practices are constantly being evolved and old ones are scrapped without regret as soon as new and better ones appear.

Another significant passage in the report on the training of operatives is that referring to status in American industry. It appears that there is a steady movement towards a position where all those in supervisory posts will have college or university degrees, all journeymen and apprentices will be high-school graduates and most other employees will have had high-school education up to the age of seventeen or eighteen. "If we remember, too, that many, perhaps most, of the best pupils from the high schools enter industry (most of our best pupils enter the professions), we may ponder on the profound effect this trend is having and will continue to have on the efficiency of American industry." Much of the development, particularly in the training of teachers, has been recent: in fifty years the highschool population has increased from about one-third of a million to more than six millions, and is now about 25 per cent of the total enrolment instead of 2.5 per cent. Any country might well be proud of what has been accomplished, and the Team records further its considered opinion that educational policy in the United States is being so shaped that these achievements will be censolidated and progress main. tained throughout the second half of the century.

The report notes that the American approach to vocational training is marked by a refreshing willingness to experiment and by a freedom from tradition and prejudice. Both management and labour recognize the urgency of the current training problem in industry ; employers regard training as an investment, and unions are willing to vary regulations as circumstances demand. The value of training schemes, however, depends not only on the degree of such goodwill but also on the degree in which employers and unions succeed in working together; but the fairly free general movement from lower to higher paid jobs encourages the worker to take advantage of the training offered. 
The Team was appointed by the Anglo-American Council on Productivity "to study the selection and training for and within industry of operatives by trade schools and other institutions and by industries, both as semi-skilled production workers and as apprentices or journeymen in their skilled trades and in the utility services. Also the further training and re-training and regrading of these workers to become more skilled and productive". The chief points in American practice which the Team recommends should be followed in Great Britain, having regard to differing background and differences in way of life, are in regard to a higher school-leaving age, the administration of vocational training by practical people, the age and duration of apprenticeship, the promotion of closer co-operation between educational establishments and industries, the improvement of training within industry and the spotting of talent (but by British rather than American methods) and the study of principles of training used at the Kelly Air Base with the view of their application in industry in Britain, particularly in achieving greater adaptability of the individual worker. On the other hand, it believes that the United States will eventually find it desirable to adopt something on the lines of the British system of National Service in place of the rather arbitrary system at present operated; and, apart from requiring training of instructors in practical subjects to take courses in teaching methods, the Team does not consider we in Britain have much to learn from the organization and administration of vocational schools and institutes in America.

Specifically the Team considers it likely that an increasing proportion of young people in the United Kingdom will in the future continue their full-time education until they are seventeen or eighteen, and most of the Team believed this tendency can only operate to the advantage of industry and of the individual, provided the instruction in the schools is realistic, and anything which can be done to accelerate it should be encouraged. With regard to apprenticeship, it urges strongly very careful re-examination by all industries of the question of age-limits and periods of training, particularly now that compulsory National Service has become a permanent feature of British life. The American system, in which the upper age limit of prospective apprentices is almost completely disregarded, is more flexible and suited to modern conditions than the rigid practice in Britain of restricting the age of entry to sixteen. It also suggests that the American practice of giving credits to apprentices for work at vocational schools should be investigated by more industries, as well as the system of making the indenture between the apprentice and the local joint apprenticeship committee. Some trade unions in Britain might, with advantage to employer and employed, insist upon higher standards for admission to the ranks of their skilled workers.

The Team which investigated the status and duties of American industrial supervisors and the methods used for selecting and training them was impressed with the way in which supervisor selection and training is treated as a matter of high policy affecting all members of management, from the company president down to foreman. The difference between the advisory or staff function and the executive or line responsibility is clearly understood, and authority is clearly defined and widely delegated. Although the American foreman occupies the lowest rung of the supervisory ladder, he is regarded as part of the management and is seen as such by his operatives. $\mathrm{H}_{\theta}$ is usually intelligent, ambitious, productionminded and cost-conscious, and his management status is emphasized by full management privileges and constant consultation with him on.plant policy. Stress is laid on his understanding that success in handling the men or women he controls is the true measure of his practical efficiency. An adequate standard of technical ability is taken for granted.

As regards selection, the Team found the main lesson of American practice not so much in details of procedures as in the general emphasis on systematic selection and the open-minded and innovating attitude. In range and thoroughness it considers that supervisor training in the United States surpasses corresponding activity in Britain. In the typical large company, the first key principle is that training of supervisors should be done mainly within the company in terms of its own policy and practice rather than by an outside agency. The second principle is that all members of the line organization are responsible for applying supervisor training; it is a tool of management in normal operations: Higher management is reluctant to impose formal training, preferring that the training staff should consult with factory and office managers in assessing training needs. Training programmes are then initiated and are continuous and progressive in character, basod on weekly or monthly sessions during working hours. Both individual and group methods are used, though a combination is preferred. The former are the most effective but are also the most difficult to adopt. The success of group methods depends largely on the skilled use of conference techniques, as does the success of the 'case studies' which are being effectively developed as a means of instruction. In all supervisor training schemes the approach is practical, but training in 'human relations' predominates. Other subjects commonly included in training programmes are work study, effective epeech and report writing, costing and budgetary control and conference leadership ; but the Team is uncertain as to the merits of including coursos on economics and the like. There appeared to be some danger of excessive reliance on visual aids. All the large companies visited were spending substantial sums on supervisory training and obviously believed in its beneficial effect on productive efficiency. Little supervisor training, as such, is available through universities and colleges of technology in the United States, but some important research and survey work is undortaken by such institutions, and the Team emphasizes the need for further research in the field of supervision. It recommends that the attention of appropriate educational and professional institutions should be directed to the study of training methods applicable in industry.

Besides this it emphasizes, in conclusion, the contribution which could be made to productivity by careful selection and training of supervisors and the need for well-informed and sustained support of such development by the highest level of management. A systematic approach to the selection of supervisors at all levels should be widely adopted and all supervisors should be regarded as responsible members of the management team. More effective provision of advice and of training courses for linemanagement trainers is required to meet the requirements of smaller firms, and most points noted above are singled out as worthy of serious consideration in British industry. 